\title{
Once The Eldery, Now The Youth : Epidemiological Study Of Non-Communicable Diseases Among Children Under 15 Years Of Age In Yaoundé-Cameroon
}

\author{
H. Blaise Nguendo Yongsi
}

\begin{abstract}
Background: In sub-Saharan Africa, communicable diseases have long been among the most prominent contributors to disease burden. However, like most low-income and middle-income countries across the globe, countries in sub-Saharan Africa are experiencing a shift from disease-burden profiles dominated by communicable diseases and childhood illnesses to profiles featuring an increasing predominance of chronic, non-communicable diseases (NCDs). Objective : The main objective of this study is to investigate the magnitude of non-communicable chronic diseases at the Chantal Biya Foundation in Yaoundé. Design and participants: This is an institution-based and cross-sectional study conducted from january to december 2018. Participants were in and out patients who visited the institution and whose a medical condition was clearly diagnosed. Results : Of the 643 medical records, leading causes of visit were infectious diseases $(51.1 \%)$, followed by NCDs (48.9\%). Diagnosed NCDs range from sickle cell disease $(5.7 \%)$, injuries $(\mathbf{9 . 8 \%})$, cardiovascular diseases $(12.0 \%)$, to cancers $(25.0 \%)$. Conclusion There is a significant burden of NCDs among adolescents in Yaoundé. Then, interventions for primordial prevention (ie, actions to inhibit the emergence of NCD risk factors) and primary prevention (ie, actions on existing NCD risk factors), as well as educational programmes on leading modifiable behavioural risk factors and metabolic risk factors are crucial.
\end{abstract}

Index Terms - Epidemiology; Non-communicable diseases; Children under five years; Chantal Biya healthcare, Yaoundé, Cameroon.

\section{INTRODUCTION}

Non communicable diseases (NCDs), also known as chronic diseases, are diseases of long duration, generally slow in progression. NCDs have today surpassed infectious diseases as the major cause of mortality and morbidity. As per the world health organization, they are are by far the leading cause of death in the world, representing $71 \%$ of all annual deaths [1].

Four main diseases are generally considered to dominate NCDs mortality and morbidity: cardiovascular diseases (including heart disease and stroke), diabetes, cancers and chronic respiratory diseases (including chronic obstructive pulmonary disease (COPD) and asthma). These four groups of diseases account for over $80 \%$ of all premature NCDs deaths, and they are caused, to a large extent, by four modifiable behavioural risk factors: tobacco use, unhealthy diet, physical inactivity and harmful use of alcohol. NCDs have now reached epidemic proportions in many countries [2]. These diseases kill more than 41 million people each year, accounting for $71 \%$ of global deaths [3]. Among the victims are more than 14 million adults who, according to WHO, "die too young" - that is, between the ages of 30 and 70. NCDs also account for 21 of the leading 30 causes of agestandardized years lived with disability in 2017 [4].

Six aspects of NCDs are especially salient. First, they are not only, or even mostly, a problem of wealthy countries. Low- and middle-income countries (LMICs) account for $86 \%$ of the burden of premature deaths from NCDs [5-6], reflecting what has been known for nearly half a century as the "epidemiologic transition" [7]. Second, the economic implications of NCDs are substantial, with a projected cost to the global economy of $\$ 47$ trillion over the next 20 years [8]. Particularly in LMICs, NCDs slow economic development and trap millions of people in poverty. Third, though NCDs are the result of a combination of genetic, physiological, environmental and behaviours factors, many risk factors for NCDs are behavioural in origin or may be influenced by the lifetstyle. Fourth, NCDs are expected to rise substantially in the coming decades, partly due to a growing ageing global population. Further, as urbanization and globalization increase in the developing world, there is likely to be an increase in the prevalence NCDs. Therefore, unless the NCD epidemic is aggressively confronted, the mounting impact of NCDs will continue unabated [9]. Fith, about one-quarter of all NCDs deaths were below the age of 60 (assuming rejuvenation of the population at risk), amounting to approximately 9 million deaths per year up of which, $90 \%$ of premature deaths occur in developing countries [10]. Sixth, the greatest increases will be in the subsaharan africa region, where they will increase by over $20 \%$. In fact, it is projected that over the next 20 years in subsahara Africa, annual infectious disease deaths will decline by around 7 million, but annual cardiovascular disease mortality will increase by 6 million, and annual cancer deaths by 4 million. By 2030, NCDs will be responsible for three times as many disability adjusted life years (DALYs) and nearly five times the mortality from communicable diseases, as well as from maternal and perinatal conditions, and nutritional deficiencies combined [11].

As such, NCDs are likely to pose devastating health consequences for individuals, families and communities, and threaten to overwhelm health systems. In other words, NCDs are not only a health problem but a development challenge as well. That's why, the WHO global NCD Action Plan 2013- 
2020 outlines global targets to reduce mortality due to major NCDs [12]. To achieve these targets, health systems will need to be equipped to address the changing patterns of disease burden. However, according to the NCD policy indicators outlined in the action plan, countries across sub-saharan Africa do not have the appropriate measures in place to aid with reaching the targets. In many of those countries, health systems remain fragile, fragmented, under-resourced, and limited in terms of infrastructure and capacity to address the increasing burden of NCDs [13]. Moreover, NCDs have not received equal attention with communicable diseases. There is inadequate information with regard to the epidemiology of NCDs for governments to develop NCD-related action plans, leaving major policy gaps for intervention. Hence, specific epidemiological studies are required for a better understanding of the burden and risks factors of NCDs. In Cameroon, WHO 2016 country profile reported that $35 \%$ of total deaths were associated with NCDs. It was also estimated that the probability of dying between ages 30 and 70 years from the four main NCDs was $17 \%$. Despite these facts, these diseases have not been given adequate attention due to the overwhelming burden of infectious diseases [14].

In the context of epidemiologic transition, a double burden of disease is already emerging with mix of persistent communicable disease and increasing NCDs [15]. However, the burden of NDCs is believed to be under estimated due to lack of reliable data and lack of disease registration system. A reliable description of diseases and their risk factors is an important input to planning and decision- making, mostly in this country (Cameroon) where the healthcare system is not designed for chronic healthcare, whose costs are huge, Since Cameroon is known to have a young population (45\% are below age 15) and that NCDs are generally low in progression, we thought that it was time to assess their magnitude and associated risks factors at the population level for easy and cost-effective prevention. Thus, this study was designed to provide local evidence on burden of NCDs to inform decision-makers and improve planning on NCDs in the city.

\section{Methodology}

\section{A. Study design and setting}

This $\mathrm{s}$ an institution-based retrospective study conducted from january 2017 to december 2018 at the pediatric unit of the Chantal Biya Foundation, located in Yaoundé. Yaoundé metropolis has several high level hospitals such as the Yaounde university hospital, the Yaounde central hospital, and the Yaoundé Gynaeco-obstetrics and pediatrics hospital, However Chantal Biya Foundation is the highest and specialized in caring for women and children under 15 . Created in 1994, the purpose of the foundation is to provide health care to the socially unprotected segments of the population and to relieve the suffering of Cameroonian population. Taking advantage of the financial support from the Presidency of the Republic, the foundation is wellequipped to diagnose NCDs, and has technical experts resources able and available to establish right diagnoses and find right remedies.

\section{B. Participants and sample size}

The study population includes patients under 15 years of age who visited the pediatric unit of the foundation between 1 July 2017 and 31 December 2018. Sample size was calculated by using the following single population formula :

$$
n \geq\left[\frac{z \alpha / 2}{E}\right]^{2} p(1-p)
$$

Where $\mathrm{n}=$ sample size, $\mathrm{P}=$ proportion of population, $\mathrm{Z}=$ reliability coefficient and $\mathrm{d}=$ margin of error. So, using $\mathrm{P}=$ $37 \%$ as WHO 2016 report stated, $\mathrm{Z}=1.96$ reliability coefficient for $95 \%$ confidence interval and $d=0.05$, sample size for the facility (Chantal Biya Foundation) per year was 358 . Since two years record were reviewed, 716 records were expected to be reviewed; an account we rounded at 750 .

Data collection technique and variables collected: Because of the challenge to review patients health card due to their mixing with other facilities and to missing information, we used registers available at the pediatric unit to review caseloads. We collected all existing registration books (including inpatients and outpatients) and counted positive diagnosed cases in each registration book. During review, records with incomplete, missing or un-readable data were replaced with next records to compensate sample size and continued until specified sample size was filled. Data were collected by mixed teams made up of master's students from the Institute of population studies (IFORD) and from the School of health Sciences. These trained data collectors used structured and pre-tested checklist. In each patient's record, they extracted socio-demographic data, final diagnosis and outcome (alive/dead). For multiple health conditions, specialists were consulted to classify main diagnosis. Health conditions were classified into: (i) infectious diseases, (ii) non-communicable diseases, and (iii) injuries. Household wealth index was computed for urban and rural residents separately, using the principal component analysis (PCA). Urban wealth status was calculated by considering properties like selected household assets, whereas only tropical livestock unit was used to determine rural income residents. In the PCA, an Eigen value of $>1$, Kaiser-Mayer-Olkin (KMO) distribution and, in the final model, common factor scores were summed and ranked into lowest, middle, second, fourth and highest.

Data management : Data entry and cleaning was done using Epi Info version 7 (free from access at http://wwwn.cdc.gov/epiinfo/7/index.htm), while descriptive analysis was done using SPSS version 18 for windows (downloadable at https://pasw.fr.malavida.com). Data cleaning was done by going through the variables one by one and cross tabulating to check for any inconsistencies and outlying values. Errors during data entry were resolved by going back to the original checklist. Frequencies and percentage of different variables were computed and the results were presented using tables and figures.

Ethical considerations: Ethical clearance was obtained from the Institutional Review Board (IRB) of the Schoolf Health 
Science of the Catholic University of Central Africa before starting data collection. Furthermore, the study protocol was approved by the Director of the Chantal Biya Foundation who allowed access to registries and patients' files. Moreover, the confidentiality of information was guaranteed by using code numbers rather than personal identifiers and by keeping the data securely locked up.

\section{RESULTS}

Patients socio-demographic characteristics: Out of the 750 medical records consulted, 643 were found complete and suitable for analyses, that is a coverage rate of $85.6 \%$. The age distribution showed a large number of patients were in age group of $10-15(40.1 \%)$ and of 5-10 years old (33.2\%). $61.9 \%$ of the study population was men and the majority lived in urban areas $(67.6 \%)$. Christianity is the dominant religion, accounting for $74.8 \%$ of the patients (Catholics and Protestants). With regard to the wealth index, the majority of patients falls within the third quintile $(36.5 \%)$. The overview of socio-demographic characateristics is depicted in table 1.

TABLE 1. SOCIODEMOGRAPHIC CHARACTERISTICS OF THE POPULATION

\begin{tabular}{|c|c|c|}
\hline Variable & Frequency & Percentage \\
\hline \multicolumn{3}{|l|}{ Age } \\
\hline $0-5$ & 171 & 26.7 \\
\hline $5-10$ & 214 & 33.2 \\
\hline $10-15$ & 258 & 40.1 \\
\hline \multicolumn{3}{|l|}{ Gender } \\
\hline Male & 398 & 61.9 \\
\hline Female & 245 & 38.1 \\
\hline \multicolumn{3}{|l|}{ Area of residence } \\
\hline Urban & 435 & 67.6 \\
\hline Rural & 208 & 32.4 \\
\hline \multicolumn{3}{|l|}{ Religious affiliation } \\
\hline Catholic & 264 & 41.1 \\
\hline Protestant & 217 & 33.7 \\
\hline Muslim & 79 & 12.3 \\
\hline No affiliation & 83 & 12.9 \\
\hline \multicolumn{3}{|l|}{ Father occupation } \\
\hline Businessman & 84 & 13.1 \\
\hline Teacher & 70 & 10.9 \\
\hline Civil servant & 104 & 16.2 \\
\hline Farmer & 91 & 14.2 \\
\hline Retired & 64 & 09.8 \\
\hline Employed contract & 129 & 20.1 \\
\hline Army/Police & 101 & 15.7 \\
\hline \multicolumn{3}{|c|}{ Household Wealth status } \\
\hline Poorest quintile & 93 & 14.5 \\
\hline Second quintile & 188 & 29.3 \\
\hline Third quintile & 235 & 36.5 \\
\hline Fourth quintile & 94 & 14.6 \\
\hline Richest quintile & 33 & 05.1 \\
\hline
\end{tabular}

Health conditions : Of the 643 medical records, leading causes of visit were infectious diseases which accounted for 328 (51.1\%), followed by NCDs with 284 ie $44.2 \%$ (95\% CI, 1.62 to 1.82). However, when cases of injuries are added $(04.8 \%)$, NCDs figure is roughly half of the health conditions, i.e. $48.9 \%$. (Figure 1 ).

Figure 1. Distribution Of Health Conditions Among Patients

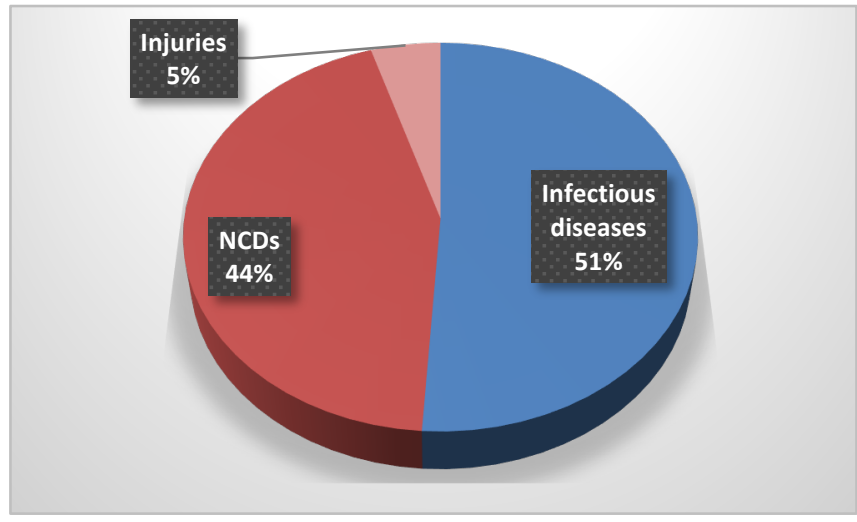

Health burden of NCDs and chronic NCDs: Approximately $48.9 \%(n=315)$ of the total study population had one or more NCDs. Diagnosed health conditions range from digestive disorders $(6.7 \%)$, cardiovascular diseases $(12.0 \%)$, diabetes type-1 $(5.0 \%)$, chronic respiratory disease (18.1\%), sickle cell disease (5.7\%), renal impairment (4.1\%), obesity and overweight $(7.3 \%)$, cancers $(25.0 \%)$, to injuries $(9.8 \%)$. Higher rates were generally seen in men compared with women for all NCDs except sickle cell disease. The detailed characteristics are depicted in table 2.

TABLE 2 PROPORTION OF NCDS BY AGE AND SEX AMONG UNDER 15 YEARS PATIENTS, YAOUNDÉ

\begin{tabular}{|c|c|c|c|c|c|}
\hline \multirow[b]{2}{*}{$\begin{array}{c}\text { Main } \\
\text { Health } \\
\text { condition }\end{array}$} & \multirow[b]{2}{*}{ Sub-type } & \multirow[b]{2}{*}{ Gender } & \multicolumn{3}{|c|}{ Years } \\
\hline & & & $\begin{array}{l}{[0-} \\
5[\end{array}$ & $\begin{array}{l}{[5-} \\
10[\end{array}$ & $\begin{array}{c}{[10} \\
- \\
15]\end{array}$ \\
\hline \multirow{12}{*}{$\begin{array}{c}\text { Cancers } \\
(n=79)\end{array}$} & \multirow[t]{2}{*}{ Leukemia } & $\mathrm{M}$ & --- & $\begin{array}{c}10 . \\
1\end{array}$ & $\begin{array}{c}06 \\
3\end{array}$ \\
\hline & & $\mathrm{F}$ & $\begin{array}{c}03 \\
8\end{array}$ & $\begin{array}{c}06 . \\
3\end{array}$ & $\begin{array}{c}05 \\
1\end{array}$ \\
\hline & \multirow[t]{2}{*}{ Brain tumor } & M & --- & $\begin{array}{c}05 . \\
1\end{array}$ & $\begin{array}{c}03 \\
8\end{array}$ \\
\hline & & $\mathrm{F}$ & $\begin{array}{c}02 . \\
5\end{array}$ & - & - \\
\hline & \multirow[t]{2}{*}{ Ocular cancer } & M & $\begin{array}{c}01 . \\
3\end{array}$ & $\begin{array}{c}03 . \\
8\end{array}$ & --- \\
\hline & & $\mathrm{F}$ & --- & $\begin{array}{c}02 . \\
5\end{array}$ & $\begin{array}{c}01 \\
3\end{array}$ \\
\hline & \multirow[t]{2}{*}{$\begin{array}{l}\text { Lymph node } \\
\text { metataxis }\end{array}$} & M & --- & $\begin{array}{c}05 . \\
1\end{array}$ & -- \\
\hline & & $\mathrm{F}$ & --- & $\begin{array}{c}07 . \\
6\end{array}$ & $\begin{array}{c}10 \\
1\end{array}$ \\
\hline & \multirow[t]{2}{*}{$\begin{array}{c}\text { Nephroblasto } \\
\text { ma, }\end{array}$} & M & -- & $\begin{array}{c}07 . \\
6\end{array}$ & $\begin{array}{c}08 \\
9\end{array}$ \\
\hline & & $\mathrm{F}$ & $\begin{array}{c}01 . \\
3\end{array}$ & $\begin{array}{c}03 . \\
8\end{array}$ & $\begin{array}{c}03 \\
8\end{array}$ \\
\hline & \multirow[t]{2}{*}{$\begin{array}{l}\text { Congenital } \\
\text { heart defect }\end{array}$} & M & $\begin{array}{c}02 . \\
6\end{array}$ & $\begin{array}{c}05 . \\
7\end{array}$ & --- \\
\hline & & $\mathrm{F}$ & $\begin{array}{c}05 \\
3\end{array}$ & --- & --- \\
\hline \multirow{2}{*}{$\begin{array}{c}\text { Cardiovasc } \\
\text { ular } \\
\text { diseases } \\
(\mathrm{n}=38)\end{array}$} & \multirow[t]{2}{*}{$\begin{array}{c}\text { Acquired } \\
\text { heart disease }\end{array}$} & M & $\begin{array}{c}02 . \\
6\end{array}$ & $\begin{array}{c}02 . \\
6\end{array}$ & $\begin{array}{r}07 \\
9\end{array}$ \\
\hline & & $\mathrm{F}$ & --- & $\begin{array}{c}05 . \\
3\end{array}$ & $\begin{array}{r}02 \\
6 \\
\end{array}$ \\
\hline
\end{tabular}




\begin{tabular}{|c|c|c|c|c|c|}
\hline & $\begin{array}{l}\text { Cardiomyopat } \\
\text { hy }\end{array}$ & M & $\begin{array}{c}05 . \\
2\end{array}$ & $\begin{array}{c}02 . \\
6\end{array}$ & $\begin{array}{c}05 . \\
3\end{array}$ \\
\hline & & $\mathrm{F}$ & --- & --- & --- \\
\hline & heart & $\mathrm{M}$ & 07. & 02. & 05. \\
\hline & arrhythmia. & & 9 & 6 & 3 \\
\hline & & $\mathrm{F}$ & $\begin{array}{c}15 . \\
8\end{array}$ & 02. & 02. \\
\hline & $\begin{array}{l}\text { cerebrovascul } \\
\text { ar disease }\end{array}$ & M & -- & $\begin{array}{c}10 . \\
5\end{array}$ & -- \\
\hline & & $\mathrm{F}$ & $\begin{array}{c}02 . \\
6\end{array}$ & $\begin{array}{c}02 . \\
6\end{array}$ & --- \\
\hline $\begin{array}{l}\text { Diabetes } \\
(\mathrm{n}=16)\end{array}$ & $\begin{array}{l}\text { Type } 1 \\
\text { diabete }\end{array}$ & M & $\begin{array}{c}12 . \\
5\end{array}$ & $\begin{array}{c}43 . \\
7\end{array}$ & $\begin{array}{c}06 . \\
2\end{array}$ \\
\hline & & $\mathrm{F}$ & --- & $\begin{array}{c}25 . \\
0\end{array}$ & $\begin{array}{c}12 . \\
5\end{array}$ \\
\hline $\begin{array}{l}\text { Sickle cell } \\
\text { disease }\end{array}$ & --- & M & $\begin{array}{c}16 . \\
7\end{array}$ & --- & $\begin{array}{c}22 . \\
2\end{array}$ \\
\hline$(\mathrm{n}=18)$ & & $\mathrm{F}$ & $\begin{array}{c}05 . \\
5\end{array}$ & $\begin{array}{c}27 . \\
8\end{array}$ & $\begin{array}{c}16 . \\
7\end{array}$ \\
\hline & Asthma & M & 1.7 & 8.8 & --- \\
\hline & & $\mathrm{F}$ & 5.3 & 8.8 & 3.5 \\
\hline $\begin{array}{l}\text { chronic } \\
\text { respiratory }\end{array}$ & $\begin{array}{l}\text { Chronic } \\
\text { respiratory }\end{array}$ & M & $\begin{array}{c}10 . \\
5\end{array}$ & 5.3 & --- \\
\hline disease. & failure. & $\mathrm{F}$ & 5.3 & 1.7 & --- \\
\hline$(n=57)$ & Respiratory & M & 8.8 & 3.5 & --- \\
\hline & $\begin{array}{l}\text { distress } \\
\text { syndrome }\end{array}$ & $\mathrm{F}$ & $\begin{array}{c}12 . \\
3\end{array}$ & 8.8 & 1.7 \\
\hline & Bronchiectasi & M & 1.7 & 5.3 & --- \\
\hline & $\mathrm{S}$ & $\mathrm{F}$ & --- & 7.0 & --- \\
\hline & $\begin{array}{l}\text { Swallowing } \\
\text { problems }\end{array}$ & M & $\begin{array}{c}23 . \\
8\end{array}$ & $\begin{array}{c}14 . \\
3\end{array}$ & -- \\
\hline $\begin{array}{l}\text { Digestive } \\
\text { disorders } \\
\text { (21) }\end{array}$ & $\begin{array}{l}\text { (gastro- } \\
\text { oesophageal } \\
\text { reflux) }\end{array}$ & $\mathrm{F}$ & 9.5 & 1 & --- \\
\hline & Rectal & M & 4.8 & 9.5 & 4.8 \\
\hline & $\begin{array}{c}\text { problems ( } \\
\text { hemorrhoids) }\end{array}$ & $\mathrm{F}$ & -- & 9.5 & --- \\
\hline & intestinal & $\mathrm{M}$ & -- & 4.8 & 4.8 \\
\hline & 1schemia & $\mathrm{F}$ & 4.8 & 4.8 & -- \\
\hline $\begin{array}{c}\text { Renal } \\
\text { impairment }\end{array}$ & --- & M & 7.7 & $\begin{array}{c}23 . \\
1\end{array}$ & $\begin{array}{c}53 . \\
8\end{array}$ \\
\hline (13) & & $\mathrm{F}$ & --- & 7.7 & $\begin{array}{c}23 . \\
1\end{array}$ \\
\hline $\begin{array}{c}\text { Overweight } \\
\text { /Obesity }\end{array}$ & --- & M & $\begin{array}{c}13 . \\
1\end{array}$ & 8.7 & $\begin{array}{c}30 . \\
4\end{array}$ \\
\hline$(\mathrm{n}=23)$ & & $\mathrm{F}$ & 8.7 & $\begin{array}{c}17 . \\
4\end{array}$ & $\begin{array}{c}21 . \\
8\end{array}$ \\
\hline $\begin{array}{l}\text { Hypertensi } \\
\text { on }\end{array}$ & --- & M & --- & $\begin{array}{c}21 . \\
1\end{array}$ & $\begin{array}{c}36 . \\
8\end{array}$ \\
\hline$(n=19)$ & & $\mathrm{F}$ & 5.3 & $\begin{array}{c}15 . \\
8\end{array}$ & $\begin{array}{c}21 . \\
1\end{array}$ \\
\hline $\begin{array}{c}\text { Injuries } \\
(\mathrm{n}=31)\end{array}$ & --- & M & $\begin{array}{c}13 . \\
0\end{array}$ & $\begin{array}{c}22 . \\
6\end{array}$ & $\begin{array}{c}29 . \\
0\end{array}$ \\
\hline & & $\mathrm{F}$ & 3.2 & 9.7 & $\begin{array}{r}22 . \\
6\end{array}$ \\
\hline
\end{tabular}

A rural-urban and poor-rich divide : The prevalence of most NCDs was slightly higher among citydwellers patients in all social groups, except injuries $(74.2 \%$ in rural vs 25.8 in urban). Table 3 shows that, low and middle social groups are the most exposed in any health condition as they account for $46.7 \%$ and $34.3 \%$ respectively, versus $19 \%$ for the upper social class.
TABLE 3 PROPORTION OF NCDS BY AREA OF RESIDENCE AND WEALTH INDEX

\begin{tabular}{|c|c|c|c|c|}
\hline \multirow[b]{2}{*}{$\begin{array}{c}\text { Main Health } \\
\text { condition }\end{array}$} & \multirow[b]{2}{*}{$\begin{array}{l}\text { Area of } \\
\text { residence }\end{array}$} & \multicolumn{3}{|c|}{ Wealth index } \\
\hline & & $\begin{array}{c}\text { Lower } \\
\text { social } \\
\text { class } \\
\text { (poorest } \\
\& 2^{\text {nd }} \\
\text { quintile) }\end{array}$ & $\begin{array}{c}\text { Middle } \\
\text { social } \\
\text { class } \\
\text { (3rd } \\
\text { quintile) }\end{array}$ & $\begin{array}{c}\text { Upper } \\
\text { social } \\
\text { class } \\
\text { (4rth } \\
\text { \& richest } \\
\text { quintile) }\end{array}$ \\
\hline \multirow{3}{*}{ Cancers $(n=79)$} & Rural & 24.1 & 8.9 & 1.3 \\
\hline & Urban & 15.2 & 29.1 & 21.4 \\
\hline & Rural & 28.9 & 18.4 & 5.3 \\
\hline \multirow{3}{*}{$\begin{array}{l}\text { Cardiovascular } \\
\text { diseases }(n=38) \\
\text { Diabetes }(n=16)\end{array}$} & Urban & 21.1 & 15.8 & 10.5 \\
\hline & Rural & 25.1 & 12.5 & --- \\
\hline & Urban & 12.5 & 31.2 & 18.7 \\
\hline \multirow{2}{*}{$\begin{array}{l}\text { Sickle cell disease } \\
\qquad(\mathrm{n}=18)\end{array}$} & Rural & 27.8 & 11.2 & --- \\
\hline & Urban & 33.2 & 27.8 & -- \\
\hline \multirow{2}{*}{$\begin{array}{l}\text { Chronic respiratory } \\
\text { disease }(n=57)\end{array}$} & Rural & 19.3 & 10.5 & 3.5 \\
\hline & Urban & 40.3 & 19.3 & 7.1 \\
\hline \multirow{2}{*}{$\begin{array}{l}\text { Digestive disorders } \\
\qquad(\mathrm{n}=21)\end{array}$} & Rural & 14.3 & 23.8 & 9.5 \\
\hline & Urban & 23.8 & 9.5 & 19.1 \\
\hline \multirow{2}{*}{$\begin{array}{l}\text { Renal impairment } \\
\qquad(\mathrm{n}=13)\end{array}$} & Rural & 30.7 & 7.7 & 7.7 \\
\hline & Urban & 30.7 & 23.2 & --- \\
\hline \multirow{2}{*}{$\begin{array}{l}\text { Overweight/Obesity } \\
\qquad(n=23)\end{array}$} & Rural & --- & --- & 8.7 \\
\hline & Urban & 30.4 & 21.7 & 39.1 \\
\hline \multirow[t]{2}{*}{ Hypertension $(\mathrm{n}=19)$} & Rural & --- & --- & --- \\
\hline & Urban & 21.1 & 36.8 & 42.1 \\
\hline \multirow[t]{2}{*}{ Injuries $(n=31)$} & Rural & 45.2 & 29.1 & --- \\
\hline & Urban & 16.1 & 6.4 & 3.2 \\
\hline
\end{tabular}

\section{DISCUSSION}

Prevalence of NCDs among adolescents in the city of Yaoundé is reported to be at least high, otherwise on the rise. Although the burden of disease continues to be dominated by infectious diseases, the city and by extension the country, is experiencing a demographic and even epidemiologic transition leading to increasing prevalence of noncommunicable diseases (NCDs).

It should be noted that similar studies done in Sub-Saharan countries showed that NCDs are now the second most common causes of morbidity and mortality after infectious diseases ${ }^{[16-17]}$. This double burden has a negative economic implication on individuals. In India for example, Thakur et al (2011) showed that the average out-of-pocket expense per stay for inpatient treatment for NCDs was almost two times than for non-NCDs whether the treatment was in public or private facilities ${ }^{[18]}$. Mahal et al. (2010) also found that 25\% of families with a member with both infectious and NCDs experience catastrophic expenditure and that the situation was much worse with cancer, where almost $50 \%$ of households with a member with joint tuberculosis and cancer experience catastrophic spending and $25 \%$ were driven to poverty by healthcare expenses ${ }^{[19]}$.

Living much closer to poverty line, these households face much higher risk of falling into poverty trap if treatment is sought and expenditure is incurred. In short, these studies show that poverty is closely linked with NCDs and the rapid rise in NCDs is predicted to impede poverty reduction initiatives. At the city or country level, socio-economic implications are also evident in the sense that, NCDs add to the city or nation's burden of poverty, slow down 
development and increase health inequities, which are believed to impose a huge demand on the healthcare system, creating economic pressure in the stakeholders ${ }^{[20-21]}$

However, that said, this study is potentially the first one in the country, describing the burden of NCDs among a relatively young age group. These findings suggest the early onset of NCDs in the population that needs to be addressed. With about $49 \%$ identified cases, this study underlines the burden and shows the rise and increase in disability caused by NCDs among the youth in the city. In this perspective, NCDs, which are set to overtake communicable diseases as the leading cause of disability and mortality over the next decade, must be recognised as major barriers to attaining Sustainable Development Goals 1, 2, and 3. Although the study population was a younger one, cancers, cardiovascular diseases, diabetes and chronic respiratory diseases were found to be the most predominant NCDs, confirming their ranking of "top four killers" and that they are the NCDs leading causes of morbidity worlwide ${ }^{[22]}$.

This study fills an important knowledge gap by providing reliable data on the magnitude of the disability burden of other NCDs in sub-Saharan Africa, such as sickle cell diseases, digestive disorders, renal impairment, and injuries. Though the global results reveal a balanced distribution for vulnerability to NCDs, trends show women compared with men are less likely to report worse overall health. Such is the case of cancers and cardiovascular diseases which have been found to be more prevalent to men than to women. Previous studies have reported significant differences in health status and NCD prevalence between men and women ${ }^{[23-24]}$. These can be attributed to the different levels of exposure and vulnerability to NCD risk factors. With reference to socioeconomic cateogory, overweight/obesity, hypertension and some types of cancers were more experienced in the highest socioeconomic group compared with the lowest socioeconomic group. This can be explained by the fact that people with better economic status will be more likely to favour mechanisation which in turn leads to transition from physically active to less physically active sedentary lifestyle, keeping kids indoors. Moreover, people with better economic status will be more likely to follow unhealthy eating habits as they can afford diets richer in unsaturated fat, thereby being more susceptible to obesity and development of NCDs ${ }^{[25] \text {. }}$

What it has been noted so far is that, city dwellers patients are globally more vulnerable to NCDs than rural dwellers patients. Indeed, Chantal Biya Foundation is located in the urbanized area, but what is learnt from the litterature is that, physical activity is more common in rural than urban areas because rural dwellers often rely on agriculture and livestock as their main occupation. Our finding is consistent with the meta-analysis done by $\mathrm{Wu}$ et al (2015) on the risk factors for chronic non-communicable diseases demonstrating that sedentary lifestyle and lack of physical activities accelerate the occurrence of NCDs ${ }^{[26]}$.

It should be noted that this condition is a growing challenge to sub-Saharan countries where walking time and space are drastically reduced in urban community as compared with rural community. This reduction in physical activity associated with city life, partly explains the excessive prevalence of NCDs in urban areas.

\section{CONCLUSION}

This study was neither comprehensive, nor nationally representative. Nevertheless, she fills an important knowledge gap by providing thorough and reliable data on the magnitude of the disability burden of NCDs in the city. In fact, the study was suggestive enough of the burden of NCDs among a younger population. Even with probable underreporting, the prevalence of NCDs within this age-group is high, and will certainly increase in coming years. Unless actions are taken early, this growing burden of NCDs will overstretch the fragile health infrastructure and reverse development efforts. A paradigm shift is then needed: for example, (i) either from addressing each NCD separately (as it is the case now in cameroon with specific diseaseprogramme) to collectively addressing a cluster of diseases in an integrated manner; (ii) or from using a biomedical approach to a public health approach to NCDs (based on the principles of primary healthcare and universal access); (iii) or again from a clinical approach (as it is again currently the situation in Cameroon) to a more comprehensive approach with emphasis on primary prevention and health promotion, early detection and treatment and surveillance.

Sub-saharan cities, because of their urbanization drivers and process, are nowadays at a unique juncture in history where opposites such as infectious and chronic conditions coexist. These NCDs pose here an additional health and economic burden and their risk factors are both diverse and escalating. This rising burden can be reversed through modest investments by using a set of cost-effective approaches. High levels of commitment, good planning and coordination, community mobilization and multisectoral actions are needed to achieve this.

Since, those NCDs severely hit the city's low- and middleincome groups, they place a tremendous demand on health systems and social welfare, cause decreased productivity in the workplace, prolong disability and diminish resources within families. Their distribution is alarmingly comparable between poorest and richest groups, between urban and rural areas, and attacking nearly reproductive age group. Therefore, health systems need to be further strengthened to deliver an effective, realistic and affordable package of interventions and services for people with NCDs. In fine, primordial prevention, early detection, and appropriate treatment are key components of the response to NCDs

\section{ACKNOWLEDGMENT}

Acknowledgements : The author would like to extend his thanks to the Chantal Biya Foundation Office for his permission to conduct the study. He also wants to express his gratitude to all staff and the study participants.

\section{Competing interests : None.}

Ethics approval : Catholic University of Central Africa..

\section{REFERENCES}

[1] World Health Organization. Noncommunicable Diseases Progress Monitor 2017. Geneva, WHO publications, 2017, 231 p.

[2] Naghavi M, Abajobir AA, Abbafati C, Abbas KM, Abd-Allah F. Global, regional, and national age-sex specific mortality for 264 causes of death, 1980-2016: a systematic analysis for the Global Burden of Disease Study. The Lancet. 2017; 390:1151-210. 
[3] World Health Organization. Global status report on noncommunicable diseases.http://apps.who.int/iris/bitstream/handle/10665/148114/978 9241564854_eng. pdf?sequence=1). Consulted on November 20, 2019.

[4] Vos T, Abajobir AA, Abbafati C, Abbas KM, Abate KH, et al. Global, regional, and national incidence, prevalence, and years lived with disability for 328 diseases and injuries for 195 countries, 1990-2016: a systematic analysis for the Global Burden of Disease Study 2016. Lancet; 2017, 390:1211-1259

[5] World Health Organization. Global action plan for the prevention and control of noncommunicable diseases 2013-2020. Rep., WHO, Geneva.http://apps.who.int/iris/bitstream/handle/10665/94384/97892 41506236_eng.pdf;jsessionid=71BCEA94B3F85737AB42F3C8421 6E54A?sequence $=1$. Page consulted on November 25, 2019

[6] Bygbjerg IC. Double burden of noncommunicable and infectious diseases in developing countries. Science; 2012, 337:1499-14501

[7] Omran AR. The epidemiologic transition: a theory of the epidemiology of population change. Milbank Mem. Fund. 1971, 49:509-538.

[8] Bloom DE, Cafiero ET, Jane-Llopis E, Abrahams-Gessel S, Bloom LR, et al. The Global Economic Burden of Non-Communicable Diseases. Geneva:World Econ. Forum, Harvard Sch. Public Health, $2011,7 \mathrm{p}$

[9] GBD 2017 Causes of Death Collaborators. Global, regional, and national age-sex-specific mortality for 282 causes of death in 195 countries and territories, 1980-2017: a systematic analysis for the Global Burden of Disease Study 2017. The Lancet; 2018, 392: 17361788

[10] Keates AK, Mocumbi AO, Ntsekhe M, Sliwa K, Stewart S. Cardiovascular disease in Africa: epidemiological profile and challenges. Nat Rev Cardiol. 2017; 14: 273-293

[11] World Health Organization. Report on the status of major health risk factors for non communicable diseases: WHO Africa Region, 2015. World Health Organization, 2015 https://www.afro.who.int/publications/ report-status-major-healthrisk-factors-noncommunicable-diseaseswho-african-region-0 (accessed October 7, 2019).

[12] World Health Organization. WHO Global Action Plan for the Prevention and Control of Noncommunicable Diseases 2013-2020. https://www.who.int/cardiovascular_diseases/WHO_Discussion_Pap er-Action Plan Indicators-FINAL-CORR2.pdf?ua=1). Accessed October $\overline{18}, 2019$ )

[13] Keates AK, Mocumbi AO, Ntsekhe M, Sliwa K, Stewart S. Cardiovascular disease in Africa: epidemiological profile and challenges. Nat Rev Cardiol. 2017; 14: 273-293

[14] Nguendo Yongsi H.B. Urban health : geoepidemiology of infectious diarrheas in Yaoundé-Cameroon. Paris, Connaissances et savoirs, $2016,276 \mathrm{p}$

[15] Observatoire national de la santé. 100 indicateurs de santé au Cameroun. Minsitère de la santé publique, 2018, 137p

[16] Habib SH, Saha S. Burden of non-communicable disease: Global overview. Diabetes Metab Syndr. 2010; 4:41-47.

[17] Kane J, Landes M, Carroll C, et al. A systematic review of primary care models for non-communicable disease interventions in subSaharan Africa. BMC Family Practice. 2017;18.

[18] Thakur J S, Prinja S, Garg CC, Mendis S, Menabde N. Social and Economic Implications of Noncommunicable diseases in India. Indian J Community Med. 2011;36, Suppl S1:13-22

[19] Mahal A, Karan A, Engelgau M. The Economic Implications of Noncommunicable Disease for India. Washington, DC: World Bank. $2010 ; 37 \mathrm{p}$

[20] Kengne AP, June-Rose McHiza Z, Amoah AG, Mbanya JC. Cardiovascular diseases and diabetes as economic and developmental challenges in Africa. Prog Cardiovasc Dis. 2013. 56(3): 302-313

[21] Akintunde TS, Adeomi AA, Akintunde AA. Economic burden and psycho-social implications of NonCommunicable Diseases on adults and their households in South-west Nigeria. Annals of Health Research. 2018. (4) 2: 97-107.

[22] World Health Organization. Noncommunicable diseases country profiles 2018. Geneva, WHO publications. 2018, 224 p.

[23] Liu Y, Liu G, Wu H, et al. Sex differences in non-communicable disease prevalence in China: a cross-sectional analysis of the China health and retirement longitudinal study in 2011. BMJ. 2017;7:1745017459

[24] Abebe SM, Andargie G, Shimeka A, et al. The prevalence of noncommunicable diseases in Northwest Ethiopia: survey of Dabat health and demographic surveillance system. British Medical Journal. 2017; $7: 15496$.

[25] Sanet van Zyl, Lynette J, van der Merwe, Corinna M, Andries J, Groenewald, and Van Rooyen C. Risk-factor profiles for chronic diseases of lifestyle and metabolic syndrome in an urban and rural setting in South Africa. Afr J Prim Health Care Fam Med. 2012; 4(1): 346

[26] Wu F, Guo Y, Chatterji S, et al. Common risk factors for chronic noncommunicable diseases among older adults in China, Ghana, Mexico, India, Russia and South Africa: the study on global ageing and adult health wave. BMC Public Health. 2015;15:88-118

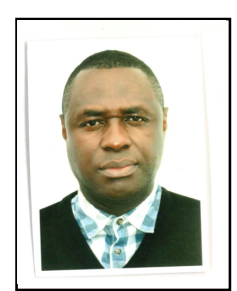

H. Blaise Nguendo Yongsi earned his BEd at Laurentian University (Canada0 and his $\mathrm{PhD}$ in Health Geography at Paris-X. He has served as a Research Professional at the Centre de Recherche Interuniversitaire de Gériatrie de Montréal and as Professor of Epidemiology and Health Geography at the U\$niversity of Chicoutmi. He is currently Associate Professor of Health Geography and Spacial Epidemiology at the Institute of Training and Research in Population Studies of the University of Yaoundé II, Cameroon. 